\title{
W
}

\section{SPRAWOZDANIE Z DZIALALNOŚCI POLSKIEGO TOWARZYSTWA TEOLOGICZNEGO W KRAKOWIE}

Polskie Towarzystwo Teologiczne w Krakowie prowadziło swoją działalność w okresie sprawozdawczym (za rok szkolny 1963/64) zgodnie ze swoim statutem na odcinku odczytowym i wydawniczym.

Działalność odczytowa prowadzona była na zebraniach ogólnych P. T. T., jak również na zebraniach sekcyjnych. Polskie Towarzystwo Teologiczne posiada obecnie 6 sekcji, a mianowicie: Sekcję filozoficzna, biblijno-liturgiczną, dogmatyczno-moralną, historyczno-prawną, apologetyczną i homiletyczno pàstoralną.

Zebrań ogólnych w okresie sprawozdawczym było 8, na których wyKerygmat $w$ pismach Nowego Testamentu (27. XI. 1963 r.), ks. prof. głoszono następujące referaty: O. prof. Augustyn Jankow s k i, OSB., Aleksy K l a we k, Nasz wspótczesny dialog z protestantami (22. I. 1964 r.), ks. prof. dr Władysław Wi cher, Ocena krytyczna Teologii Moralnej O. Bernarda Häringa (19. II. 1964 r.), o. prof. dr Walenty P r ok ulsk i TJ., O zasadę kolegialności Episkopatu w Kościele (11. III. 1964 r.), ks. prof. dr Teofil Długosz, W stulecie urodzin ks. prof. Jana Fijalıa (22. IV. 1964 r.), ks. prof. dr Ignacy R óż y cki, Zmiany $w$ dogmatycznym pojmowaniu sakramentu Namaszczenia Chorych $w$ zwiazku $z$ Konstytucja o Swiętej Liturgii, uchwalona na II Soborze Watykańskim (30. IV. 1964 r.), ks. rek. dr Marian R e chowicz z KULu, System Studiów na Wydziale Teologicznym w XV w. (12. V. 1964 r.), prof. dr Franciszek German, Z dziejów Wydziatów Teologicznego Wszechnicy Jagiellońskiej (10. VI. 1964 r.). Trzy z powyższych referatów (ks. T. Długosz, ks. rek. M. Rechowicz, prof. F. German) miały na celu uczczenie 600-lecia Uniwersytetu Jagiellońskiego i przypomniały P. T. T., najpierw ogólne dzieje Wszechnicy Jagiellońskiej, potem dzieje samego Wydziału Teologicznego oraz sylwetki wybitniejszych profesorów, szczególnie z ostatniego 40-lecia.

Działalność P.T.T., realizowana w sekcjach posiada charakter ściśle specjalistyczny i wyrażała się w referatach wygłaszanych przez fachowców-znawców poszczególnych dyscyplin filozoficzno-teologicznych. Z natury rzeczy sekcje obejmują nie wielką ilość członków, którymi są przeważnie profesorowie odpowiednich przedmiotów na Studium Teologicznym w Krakowie.

$\mathrm{Na}$ sekcji Filozoficznej, prowadzonej przez ks. prof. dra Tadeusza Wojciechowskiego w okresie sprawozdawczym wygłoszono nastepujace referaty: ks. prof. dr Kazimierz K łós ak, wygłosił dwa referaty: 1) Ks. Piotr Teilhard de Chardin a zagadnienie monogenistycznych początków ludzkości oraz referat 2) pt. Stosunek filozofii przyrody do metafizyki $u$ współczesnych polskich neoscholastyków. Poza tym wygłoszono jeszcze dwa referaty: ks. Alfons MI chalski CM., Natura $i$ psychoterapia psychastenii, ks, prof. Jan Choczewski TJ., Biochemiczne przemiany $w$ komórce między jadrem i plazma w świetle wspótczesnych badań. 
Sekcja Biblijno-Liturgiczna pod kierunkiem ks. prof. Władysława Smereki, miała 5 zebrań, na których wygłoszono następujące referaty: Kryzys we współczesnej biblistyce oraz Nasze spojrzenie na Stary Testament, uwagi na marginesie ksiązki Kosidowskiego $i$ Azebskiego. Ks. prof. Wł. Sme reka także 2 referaty: Potęga ducha św. Pawła, oraz referat pt. Metoda św. Pawta w jego misji apostolskiej, wzorem dzisiejszego duszpasterstwa. Ks. prof. T. Szw a g r y k, Idee przewodnie Konstytucji Soborowej o Swiętej Liturgii $i$ jej znaczenie.

Sekcja Dogmatyczno-moralna kierowana przez ks. prof. Ig. R óży ckiego, miała 4 zebrania z następującymi referatami: ks. prof. Ig. R óż y cki, Zagadnienie sakramentalności Episkopatu, Zmiany $w$ dogmatycznym pojmowaniu sakramentu Namaszczenia Chorych, ks. prof. Wł. W icher, Teologia Moralna O. B. Häringa $w$ świetle krytyki, ks. prof. T. Slipko, Podstawowe zagadnienia w encykiice Mater et Magistra.

Sekcja Historyczno-prawna pod kierunkiem ks. prof. Br. Natoískiego TJ., miała dwa zebrania na których wygłoszono referaty: ks. prof. T. Szwagrzyk, Motu proprio Pawta VI, pastorale munus, $w$ świetle prawa kanonicznego oraz o. prof. Kornel G a da c z OFMCAp., Dzieje duchowieństwa polskiego na Syberii po powstaniu styczniowym 1863 r. w świetle nowych badań.

Działalność sekcji apologetycznej i homiletyczno-duszpasterskiej dotyczyła problemów praktycznych i aktualnych i odbywała się na seminariach naukowych na których omawiano kwestie religioznawstwa, kaznodziejstwa i współczesnego duszpasterstwa.

-Oprócz akcji odczytowej P.T.T. prowadzi jeszcze akcję wydawniczą, obejmująca redagowanie i wydawanie czasopisma Ruch Biblijny $i$ Liturgiczny, który w nakładzie 2500 egzemplarzy ukazuje się jako dwumiesięcznik i omawia poza naukowymi artykułami, także kwestie aktualne z biblistyki jak również i z liturgii.

Czasopismo redaguje i P. T. T. prowadzi jako prezes ks. prof. Stanisław Grzybek. Polskie Towarzystwo Teologiczne liczy obecnie 124 członków i zgodnie ze statutem może rozwijać swoją działalność na terenie woj. krakowskiego.

\section{SPRAWOZDANIE Z POSIEDZEŃ POLSKIEGO TOWARZYSTWA TEOLOGICZNEGO}

(Sekcja Biblijno-liturgiczna)

Na posiedzeniu w dniu 22. X. 64 r. ks. prof. A leks y K lawek wygłosił referat na temat: Instrukcja Papieskiej Komisji Biblijnej o iristoryczności Ewangelii.

Po uwagach wstępnych i przeczytaniu Instrukcji w przekładzie polskim (por. RBL 1964, nr 4) dał referent obszerne wyjaśnienie kierunków badań biblijnych wspomnianych w ,Instrukcji”, zwłaszcza głównych zasad tzw. Formgeschichte, tj. historii pierwotnych form naszych Ewangelii.

Dopiero od roku 1919 zaczęła biblistyka posługiwać się tym wyrazem zapożyczonym od M. Nor de na (Antike Kunstprosa, Berlin 1913). Najpierw szukano podobną metodą rozmaitych kategorii form literackich w ksiegach Starego Testamentu, szczególnie pod kierunkiem prof. Uniwersytetu berlińskiego Gunkela. Autorzy piszący na ten temat dochodzili do jedromyślnego wniosku, że $w$ Biblii St. T. istnieją rozmaite rodzaje literackie (podania luciowe, dokumenty historyczne, legendy etio- 
logiczne, mity, midrasze, modlitwy, hymny, pieśni liturgiczne itp.), chociaż w szczegółach jeszcze dzisiaj po 50 latach często się różnią. Kierunek jako taki jest słuszny i również przez biblistykę katolicką obecnie w całej pełni przejęty. Przesadę pewną zauważyć można w szkole londyńskiej, będącej pod wpływem etnologa Frazera, i w szkole skandynawskiej, czyli w tzw. pattern-schools, które wszędzie widzą przejmowanie obcych, gotowych wzorców czy schematów (pattern) z kół poza-izraelskich.

O „formach pisarskich” w Ewangeliach pisał jako pierwszy prof. Dibeli us z Heidelbergu (Die Formgeschichte des Evangeliums 1919, wyd. II 1933, wyd. III 1959), a po nim K. L. S c hmidt (Der Rahmen der Geschichte Jesu 1921) i R. Bultmann (Die Geschichte der synoptischen Tradition 1919). Uprawia się tą drogą niejako ,paleontologię” Ewangelii, by dotrzeć do tajemnic kompozycyjnych, jakie one zawierają. Nie uważa sie ich za dzieła literackie, lecz zalicza do piśmiennictwa ludowego, przeznaczonego do użytku małego grona ludzi. Podstawą były nieliterackie, prywatne zapiski, przeważnie niezbyt długie, zawierające reminiscencje własne, opowiadania innych, zbiory powiedzeń P. Jezusa, tematyczne zestawienie słów dla potrzeb gminy, genealogie, hymny, modlitwy itp. Zapiski te ułożone były w takiej lub innej formie pisarskiej, zależnie od treści, od potrzeb chwili lub upodobania piszącego czy zamawiającego spisanie słów i czynów Pana Jezusa. Ponieważ zaś w okresie tworzącego się Kościoła warunki i potrzeby się zmieniały i inne myśli ze skarbca prawd ewangelicznych stawały się aktualniejsze, także treść i forma pra-ewangelii się zmieniała poprzez 30 lat, czyli aż do chwili, kiedy ułożono nasze ewangelie. Oto odtwarzanie „prehistorii” Ewangelii jest zadaniem wspólczesnej biblistyki.

Dzieje formy pisarskiej naszej Ewangelii uzupełnia ,historia pracy redakcyjnej" nad ułożeniem opisów ewangelicznych (tzw. Redaktionsgeschichte), która wnikliwie bada sposób zredagowania poszczególnych wiadomości i uporządkowania ich przez Ewangelistów lub ich poprzedników, o których wspomina początek ewangelii św. Eukasza. Dzięki tej metodzie wiemy obecnie, że kazanie na górze jest zestawieniem prawdziwych słów Pana Jezusa, niekoniecznie wypowiedzianych na gớrze Błogosławieństw, że rozdzial $18 \mathrm{u}$ św. Mateusza jest zbiorem nauk Chrystusowych o zachowanie zgody i porządku $\mathrm{w}$ gminie (por. pracę ks. Trillinga, Hausordnung Gotes. Eine Auslegung von Matthaeus 18, Diisseldorf 1960).

Jakkolwiek rozróżnienie nieliterackich form pisarskich jest uzasadnione i jakkolwiek myśmy dzięki temu lepiej poznali układ ewangelii synoptycznych i dyspozycję wielu dotąd spornych rozdziałów, to jednak może ono prowadzić do wniosków całkiem błędnych, gdyż przy braku szerszej bazy historycznej grozi nam niebezpieczeństwo dowolnego zupełnie wnioskowania. Błądzi szkoła B ultm a n a zaliczając wiele opowiadań ewangelicznych do kategorii "mitów” i nie uznając wobec tego ani historyczności Zwiastowania Anielskiego w Nazaret, ani rzeczywistości Zmartwychwstania Pana Jezusa. Nie mamy bowiem w odnośnych tekstach, podających gole fakty bez upiększających ram dodatkowych, żadnego zabarwienia mitycznego. Kto opowiadania te kwalifikuje jako mityczne, kieruje się totalnym subiektywizmem opierając się na przesądach filozoficzno-teologicznych.

Droga otwarta do tych ciekawych, ale żmudnych i trudnych badań, lecz droga jeszcze bardzo daleka do osiągnięcia historycznie pewnych rezultatów, z których będzie mogła dogmatyka wyciągać dalsze wnioski.

Red. 